\title{
Biochemical identification and molecular characterization of Klebsiella pneumoniae isolated from street foods and drinks in Yogyakarta, Indonesia using 16S rRNA gene
}

\author{
TRI YAHYA BUDIARSO ${ }^{1, \bullet}$, CHARIS AMARANTINI ${ }^{1}$, SUHENDRA PAKPAHAN ${ }^{2}$ \\ ${ }^{1}$ Department of Biology, Faculty of Biotechnology, Universitas Kristen Duta Wacana. J1. Dr. Wahidin Sudirohusodo No. 5-25, Yogyakarta 55224, \\ Yogyakarta, Indonesia. Tel./fax.: +62-274-563929, ^email: yahya@ staff.ukdw.ac.id \\ ${ }^{2}$ Research Center for Biology, National Research and Innovation Agency. Jl. Jakarta-Bogor Km 46, Cibinong, Bogor 16911, West Java, Indonesia
}

Manuscript received: 10 August 2021. Revision accepted: 24 November 2021.

\begin{abstract}
Budiarso TY, Amarantini C, Pakpahan S. 2021. Biochemical identification and molecular characterization of Klebsiella pneumoniae isolated from street foods and drinks in Yogyakarta, Indonesia using 16S rRNA gene. Biodiversitas 22: 5452-5458. Yogyakarta is best known as a student city in Indonesia. However, the fact that students spend almost full day in the school gave rise to the sale of a great variety of foods and drinks in its surrounding streets. Unfortunately, most street vendors do not pay attention to food hygiene. This study aims to identify the biochemical and molecular isolates of Klebsiella pneumoniae isolated from street foods and drinks in Yogyakarta using 16S rRNA gene. Data were collected from 120 samples of street foods and drinks sold at schools and several public places. The samples were enumerated using CCA medium to isolate suspected Klebsiella spp. colonies, then physiologically screened and identified using the API-20E kit. Positive isolates were isolated and amplified using the 16S rRNA gene marker for sequencing, which was then compared with the GenBank database to establish molecular identity. The results of biochemical identification obtained 11 isolates confirmed as $K$. pneumoniae and 1 isolate as $K$. oxytoca. The phylogenetic analysis showed that only 10 isolates were determined as $K$. pneumoniae with the reference sequences of $K$. pneumoniae from infected patients' respiratory and urinary tract. Furthermore, 2 isolates identified as Citrobacter sp. and Micrococcus sp., which are contaminated with Klebsiella spp. were highly found in street foods and drinks. Therefore, hygiene and sanitation need to be implemented when processing and serving these foods.
\end{abstract}

Keywords: drinks, Klebsiella pneumoniae, street foods, Yogyakarta, 16S rRNA

\section{INTRODUCTION}

Klebsiella pneumoniae is one of the prominent pathogens found in hospitals-acquired samples. The bacteria are notoriously responsible for foodborne diseases as septicemia, pneumonia, urinary tract infections (UTIs), liver abscess, bloodstream infection, and diarrhea (Zhang et al. 2018; Bengoechea and Pessoa 2019). Besides humans, K. pneumoniae is also pathogenic for several animals. In Egypt, it was reported to be responsible for $35 \%$ of the mortality in chicks and broilers (Hamza et al. 2016). The results of swabs from the nasal passages of 120 local Balinese cattle living in highlands and lowlands showed the presence of this bacterial in percentages of seven isolates (35\%) and thirteen isolates $(65 \%)$ respectively while in-calf cattle there were nine isolates $(45 \%)$, heifers six isolates $(30 \%)$, and adult cattle five isolates (25\%) (Ramaditya et al. 2018). Klebsiella pneumoniae was also found in the digestive tract, where it is present as microflora. This bacteria is a gram-negative, rod-shaped, anaerobic, facultative, and nonmotile bacterium that may be present in several habitats as in the soil, surface water, wastewater, plants, and drinking water (Onuoha et al. 2016; Maisonneuve et al. 2017).

Street foods are easily infested by $K$. pneumoniae, and it causes the consumers to suffer from certain health problems. Guo et al. (2016) reported that 99 strains (9.9\%) of this bacterial were present in 998 edible samples tested, and the frequency of contamination in cooked food was 7.5\%. Furthermore, Kim et al. (2015), and Zhang et al. (2018) are also discovered its presence in retail and readyto-eat food, vegetables, raw meat, and aquatic products.

Yogyakarta city offers a variety of street foods in high demand by the public, especially students. Due to the fiveday schooling activities, majorities spend most of their time in these institutes and have no choice but to buy food during break time. Based on observations carried out in this field, it was reported that street vendors (PKL) in several public places usually do not pay attention to hygiene and their environment. Many food items are contaminated, which has led to the cause of health problems, especially in developing countries (Alimi 2016).

Research on Klebsiella sp. contamination in street foods and drinks in Yogyakarta and elsewhere in Indonesia has not yet been reported. The results of coliform identification on 30 Thai Tea traders and 30 types of Thai Tea drinks with different brands in Yogyakarta showed that the contamination rate exceeded the MPN/100 ml standard (Suryani et al. 2021). This study aims to identify the biochemical and molecular isolates of $K$. pneumoniae isolated from street foods and drinks in Yogyakarta, Indonesia using $16 \mathrm{~S}$ rRNA gene. 


\section{MATERIALS AND METHODS}

\section{Collection of samples}

A total of 120 samples of street foods and drinks were obtained from schools and several public places commonly visited by people of Yogyakarta, Indonesia and surrounding areas during 2019-2020. The street foods and drinks collected were including bakso tusuk (10 samples), siomay (10 samples), cilok (10 samples), skewered eggs (10 samples), milk packaging (20 samples), grass jelly ice (10 samples), traditional milk products (10 samples), bottled drinking water (20 samples), bottled drinking tea (10 samples), and processed potato products (10 samples). The samples were transported in sterile containers to the Duta Wacana Christian University Microbiology Laboratory for isolation and identification, based on biochemical and molecular characterization.

\section{Enumeration and isolation of isolates of Klebsiella spp.}

A total of $25 \mathrm{~g} / \mathrm{mL}$ of each sample was inoculated in $225 \mathrm{ml}$ of peptone buffer water (BPW, Merck, Darmstadt Germany), and then incubated at $37^{\circ} \mathrm{C}$ overnight (Guo et al. 2016). Furthermore, the cell culture of $1 \mathrm{~mL}$ was diluted in $9 \mathrm{~mL}$ of peptone water until it became $10^{-5}$. This culture was homogenized and $0.1 \mathrm{~mL}$ inoculated in Chromocult Coliform Agar (CCA, Merck Germany) media. CCA media contains Salmon-GAL and X-Glucuronide substrates which induce bacteria to synthesize $\beta$-galactosidase and $\beta$ glucuronidase enzymes. The Klebsiella group which is capable of synthesizing $B$-glucuronidase enzyme utilized Salmon-GAL substrate for growth and development into a salmon-red colony. This colony was then separated until only one was left because of some other members of the Enterobacteriaceae family (Enterobacter spp. and Citrobacter spp.), which have the same characteristics as Klebsiella species (Maheux et al. 2017; Teramura et al. 2017).

\section{Biochemical assay using API 20E kit}

The suspected colonies of $K$. pneumoniae were purified to obtain a single colony. Furthermore, every single colony was inoculated in a BHI medium and stored as a collection of bacteria. Subsequently, all isolates were characterized at the genus level. All of Klebsiella spp. isolates were distinguished to the other genera belonging to Enterobacteriaceae family, especially Enterobacter spp. and Citrobacter spp., by a series of biochemical tests, such as indole, methyl red, motility, Voges-Proskauer, citrate, urease, carbohydrates fermentation, and $\mathrm{H}_{2} \mathrm{~S}$ formation tests. First, all of the tube tests were incubated at $37^{\circ} \mathrm{C}$ for 24-48 hours (Brenner and Farmer 2015; Cappuccino and Welsh 2017). Furthermore, to confirm their identity, the suspected isolates were subjected to a biochemical reaction using API 20E kit. The test results were then analyzed using the API $20 \mathrm{E}$ software system (Biomereoux) so that the species name and \%ID were obtained which showed the profile indexes, namely the magnitude of the similarity of the biochemical characters of the tested isolates (AlAgha et al. 2017).

\section{Selection and genetic identification of suspected Klebsiella pneumoniae using 16S rRNA}

DNA of suspected K. pneumoniae was isolated from each single-cell isolate followed the biochemical assay using Geneaid following the manufacturer's protocol. The amplification of the 16S rRNA for the sequencing analysis was carried out by polymerase chain reaction (PCR) with GoTaq Green Master Mix (Promega, USA). The universal primer for the 16S rRNA gene, namely 27F (5'-AGA GTT TGA TCM TGG CTC AG-3') and 1492R (5'-CGG TTA CCT TGT TAC GAC TT-3') were used to amplify and analyze the sequence of the 16S rRNA gene (Ibrahim 2016; Barbosa et al. 2019). PCR reaction was carried out in a 50 $\mu 1$ PCR reaction containing 2.5 U Taq DNA polymerase, 10 pmol each of the forward and reverse primers, $1 \mathrm{X}$ Taq buffer, $0.2 \mathrm{mM}$ dNTP mix, $1.5 \mathrm{mM} \mathrm{MgCl} 2$, DNA template, and sterile distilled water (1st Base, Singapore). PCR amplification was performed in a Thermal Cycler (peqSTAR) under conditions such as pre-denaturation at $94^{\circ} \mathrm{C}$ for 4 minutes, followed by 30 cycles of denaturation at $94^{\circ} \mathrm{C}$ for 1 minute; annealing at $51.5^{\circ} \mathrm{C}$ for 1 minute 30 second, and extension at $72^{\circ} \mathrm{C}$ for 2 minutes, then followed by a final extension step at $72^{\circ} \mathrm{C}$ for 10 minutes. The PCR products were visualized in $1.2 \%$ agarose gel supplemented with Green Safe Premium with 100 bp DNA Ladder were used as a molecular sizes standard (Ibrahim 2016). The gel was visualized by UV transilluminator (Alphalmager MINI, Taiwan) and the image was captured by the digital camera (computer H6ZO812, Japan).

\section{DNA sequencing}

The amplification products then were proceeded to sequencing analysis after product purification. The sequencing analysis was performed using BigDye Terminator v3.1 and the sequencing products were separated by capillary electrophoresis using an ABI PRISM 3730xl Genetic Analyzer developed by Applied Biosystems, USA.

\section{Data analysis}

The sequence of each isolate was then compared to the sequences in the GenBank database using a basic local alignment search tool (BLAST) (blast.ncbi.nlm.nih.gov). Furthermore, the 16S rRNA gene sequences were aligned to several reference sequences from GenBank using the Clustal W integrated with MEGA 7 (Kumar et al. 2016). The targeted sequence of 16S rRNA gene ( 1500 bp) from our isolates was then analyzed to determine the genetic distance followed with phylogenetic tree construction using the neighbor-joining method, and the Kimura 2-parameter model tested with 1,000 bootstrap replicates and shown at the nodes. The scale bar represents a 5\% nucleotide sequence divergence (Kumar et al. 2016). 


\section{RESULTS AND DISCUSSION}

\section{Biochemical identification and characterization of the isolates candidate of Klebsiella spp.}

Based on the isolation and selection processes, 7 out of the 120 samples of different kinds of street foods and drinks were contaminated with Klebsiella spp. (Table 1). In accordance with biochemical characterization using API $20 \mathrm{E}$, 11 out of 12 suspected isolates, were identified as $K$. pneumoniae (isolates 1 to 11 ), while the other one is $K$. oxytoca (isolate 12). The API 20E kit reagent has high validity for biochemical confirmation in bacteria especially the Enterobacteriaceae family. The evaluation of the tests conducted by Devenish and Barnum (1980) on 235 isolates from 240 strains of Enterobactericeae family showed the validity of $97.5 \%$. Maina et al. (2014) also carried out research to determine the accuracy of the API 20E test on 1425 out of 1658 bacterial isolates with $87.6 \%$ conformity or validity.

The confirmation analysis of all isolates identified as $K$. pneumoniae showed a \% ID or Analytical Profile Index within the range of $85.7 \%$ to $99 \%$. These results indicate that its biochemical characters are similar to the biomereoux software database. Meanwhile, 5 of the 12 isolates were derived from milk samples, either processed industrially or traditionally. It was further discovered that dairy products were highly contaminated with Klebsiella spp. compared to other food sources. Klebsiella pneumoniae is known to inhabit the digestive tract (Bagley 1985) temporarily, therefore, it tends to be expelled in cow feces, contaminating the dairy product during the milking process. In addition, Klebsiella sp. is often found in clinical and subclinical mastitis in cows and buffaloes (Langoni et al. 2015). Several unprocessed dairy products, such as packed milk, ice cream, and cheese, sold in the market were discovered to be contaminated with Klebsiella sp. (Saini et al. 2016; Salazar et al. 2018). Klebsiella pneumonia and K. oxytoca are microbial contaminants reportedly found in ready-to-eat foods in Osaka, Japan (Harada et al. 2018), and Windhoek, Namibia (Shiningeni et al. 2018). In Bantul, Indonesia, there has also been a food poisoning outbreak caused by Bacillus cereus and K. pneumoniae contamination in a retrospective study which was found in chicken satay or stool samples (Son et al. 2019).

\section{Genetic identification and diversity of bacteria based on 16S rRNA sequences}

All 12 isolates show a similar single band at an approximate 1500 bp size using agarose gel electrophoresis. Thus, the 12 isolates were classified as Klebsiella spp. according to amplification of the 16S rRNA gene (Figure 1). However, the sequencing results were obtained from Sanger sequencing were checked and aligned using nucleotide BLAST to ascertain the sequence similarity against the NCBI database.

Based on the results obtained, the genera with a similar identity was Klebsiella sp. for genetic analyses, which involved 25 nucleotide sequences were conducted using the Kimura 2-parameter model (Kumar et al. 2016). Codon positions included were $1 \mathrm{st}+2 \mathrm{nd}+3 \mathrm{rd}+$ Noncoding. Furthermore, all positions containing gaps and missing data were eliminated. The sequences with an average length $\sim 1350$ bp were obtained. Based on estimates of evolutionary divergence between sequences, it was proven that isolates 10 and 12 had the farthest genetic distance from $K$. pneumoniae when compared to others. Therefore, they might be belonging to different species (Table 2).

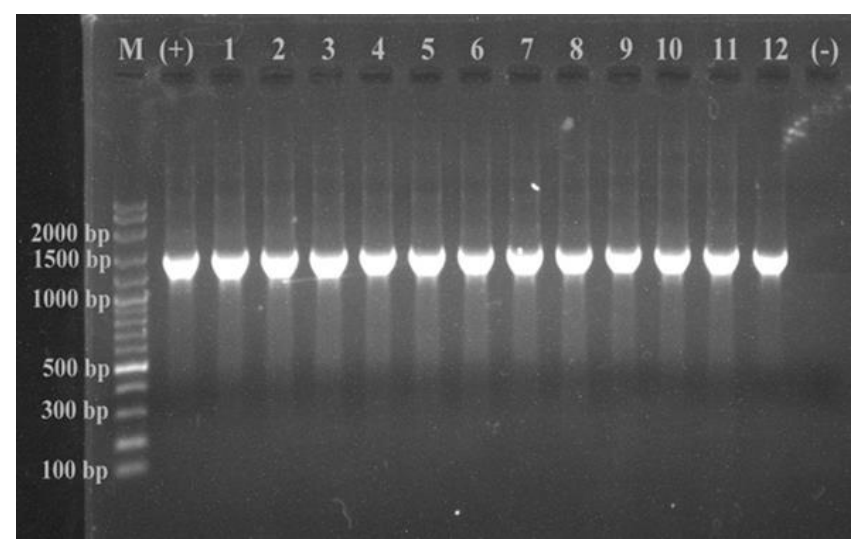

Figure 1. Quantification of PCR products of 16S rRNA gene on $1.2 \%$ agarose gel. M: DNA marker, $(+)$ : positive control $(K$. pneumoniae ATCC 25922), number 1-12: PCR product of the isolates of predicted Klebsiella spp, (-): negative control (empty template)

Table 1. Street food and drinks contaminated by Klebsiella spp. based on biochemical tested using API 20-E Kit

\begin{tabular}{|c|c|c|c|c|}
\hline Food samples & $\begin{array}{c}\text { Number of } \\
\text { samples tested }\end{array}$ & $\begin{array}{l}\text { Number of samples } \\
\text { contamination }\end{array}$ & $\begin{array}{l}\text { Code of isolates of } \\
\text { suspected Klebsiella } \\
\text { spp. }\end{array}$ & $\begin{array}{l}\text { Number of isolates identified as } \\
\text { Klebsiella spp. using the API 20E } \\
\text { kit with the \% ID }\end{array}$ \\
\hline \multirow[t]{4}{*}{ Traditional milk products } & 10 & 3 & Isolate 1 & K. pneumoniae $(85.4)$ \\
\hline & & & Isolate 2 & K. pneumoniae (97.1) \\
\hline & & & Isolate 3 & K. pneumoniae (86.1) \\
\hline & & & Isolate 4 & K. pneumoniae (85.4) \\
\hline \multirow[t]{2}{*}{ Cilok } & 10 & 2 & Isolate 5 & K. pneumoniae (95.2) \\
\hline & & & Isolate 6 & K. pneumoniae (99) \\
\hline Skewered eggs & 10 & 1 & Isolate 7 & K. pneumoniae (97.3) \\
\hline Bakso tusuk & 10 & 2 & Isolate 8 & K. pneumonia (97.3) \\
\hline Grass jelly ice & 10 & 2 & Isolate 9 & K. pneumoniae (97.3) \\
\hline \multirow[t]{2}{*}{ Bottled drinking water } & 10 & 2 & Isolate 10 & K. pneumoniae (97.3) \\
\hline & & & Isolate 11 & K. pneumoniae (97.3) \\
\hline Milk packaging & 20 & 2 & Isolate 12 & K. oxytoca $(97.8)$ \\
\hline
\end{tabular}


Table 2. Genetic distances between isolates of predicted Klebsiella spp. (R1 and R2 were reference sequences stand for Klebsiella pneumoniae strain ATCC 13883 (NR 119278.1) and K. oxytoca strain ATCC13182T (Y17655.1)

\begin{tabular}{|c|c|c|c|c|c|c|c|c|c|c|c|c|c|c|}
\hline & R1 & $\mathbf{R 2}$ & S1 & S2 & S3 & S4 & S5 & S6 & S7 & S8 & S9 & S10 & S11 & S12 \\
\hline$\overline{\mathrm{R} 1}$ & 0.000 & & & & & & & & & & & & & \\
\hline R2 & 0.022 & 0.000 & & & & & & & & & & & & \\
\hline S1 (Isolate_1) & 0.000 & 0.022 & 0.000 & & & & & & & & & & & \\
\hline S2 (Isolate_2) & 0.000 & 0.022 & 0.000 & 0.000 & & & & & & & & & & \\
\hline S3 (Isolate_3) & 0.001 & 0.021 & 0.001 & 0.001 & 0.000 & & & & & & & & & \\
\hline S4 (Isolate_4) & 0.001 & 0.021 & 0.001 & 0.001 & 0.000 & 0.000 & & & & & & & & \\
\hline S5 (Isolate_5) & 0.000 & 0.022 & 0.000 & 0.000 & 0.001 & 0.001 & 0.000 & & & & & & & \\
\hline S6 (Isolate_6) & 0.000 & 0.022 & 0.000 & 0.000 & 0.001 & 0.001 & 0.000 & 0.000 & & & & & & \\
\hline S7 (Isolate_7) & 0.001 & 0.022 & 0.001 & 0.001 & 0.002 & 0.002 & 0.001 & 0.001 & 0.000 & & & & & \\
\hline S8 (Isolate_8) & 0.001 & 0.021 & 0.001 & 0.001 & 0.003 & 0.003 & 0.001 & 0.001 & 0.001 & 0.000 & & & & \\
\hline S9 (Isolate_9) & 0.002 & 0.020 & 0.002 & 0.002 & 0.001 & 0.001 & 0.002 & 0.002 & 0.003 & 0.002 & 0.000 & & & \\
\hline S10 (Isolate_10) & 0.016 & 0.011 & 0.016 & 0.016 & 0.015 & 0.015 & 0.016 & 0.016 & 0.016 & 0.016 & 0.014 & 0.000 & & \\
\hline S11 (Isolate_11) & 0.001 & 0.022 & 0.001 & 0.001 & 0.002 & 0.002 & 0.001 & 0.001 & 0.000 & 0.001 & 0.003 & 0.016 & 0.000 & \\
\hline S12 (Isolate_12) & 0.282 & 0.280 & 0.282 & 0.282 & 0.284 & 0.284 & 0.282 & 0.282 & 0.283 & 0.282 & 0.283 & 0.283 & 0.283 & 0.000 \\
\hline
\end{tabular}

Table 3. The nucleotide variable sites between isolate samples predicted as Klebsiella sp. and K. pneumoniae strain ATCC 13883 (NR 119278.1)

\begin{tabular}{|c|c|c|c|c|c|c|c|c|c|c|c|c|c|}
\hline & 128 & 352 & 379 & 402 & 404 & 419 & 420 & 954 & 955 & 964 & 965 & 1081 & 1082 \\
\hline NR 119278.1 K. pneumoniae strain ATCC 13883 & $\mathrm{Y}$ & G & $\mathrm{C}$ & A & G & A & $\mathrm{T}$ & $\mathrm{T}$ & $\mathrm{C}$ & $\mathrm{G}$ & A & $\mathrm{T}$ & A \\
\hline CP075890.1 K. pneumoniae strain GR390 (blood) & $\mathrm{C}$ & . & . & $\mathrm{T}$ & A & G & G & . & . & . & . & $\mathrm{C}$ & $\mathrm{C}$ \\
\hline CP074198.1 K. pneumoniae strain Kp13869 (urine) & $\mathrm{C}$ & . & . & $\mathrm{T}$ & A & $\mathrm{G}$ & $\mathrm{G}$ & . & . & . & . & $\mathrm{C}$ & $\mathrm{C}$ \\
\hline $\begin{array}{l}\text { FR997879.1 K.pneumoniae isolate RH201207 } \\
\text { (clinical isolates) }\end{array}$ & $\mathrm{C}$ & . & . & $\mathrm{T}$ & A & G & $\mathrm{G}$ & . & . & . & . & $\mathrm{C}$ & $\mathrm{C}$ \\
\hline CP070579.1 K. pneumoniae strain FK 6768 (feces) & $\mathrm{C}$ & . & . & . & A & G & . & . & . & . & . & $\mathrm{C}$ & $\mathrm{C}$ \\
\hline $\begin{array}{l}\text { CP062792.1 K. pneumoniae strain } 33 \mathrm{Kpn} 12 \\
\text { (percutaneous abscess drainage) }\end{array}$ & $\mathrm{T}$ & . & . & . & A & G & . & . & . & . & . & . & $\mathrm{C}$ \\
\hline $\begin{array}{l}\text { CP035540.1 K. pneumoniae subsp. pneumoniae } \\
\text { strain CCRI-22199 (anal) }\end{array}$ & $\mathrm{T}$ & . & . & $\mathrm{T}$ & A & $\mathrm{G}$ & G & . & . & . & . & . & . \\
\hline $\begin{array}{l}\text { NR_037084.1 K. pneumoniae subsp. } \\
\text { rhinoscleromatis strain R-70 (nose) }\end{array}$ & $\mathrm{C}$ & . & . & . & A & G & . & A & G & $\mathrm{C}$ & $\mathrm{T}$ & . & . \\
\hline Klebsiella sp. (Isolate 1) & $\mathrm{C}$ & . & . & . & A & G & $\mathrm{K}$ & . & . & . & . & $\mathrm{Y}$ & $\mathrm{C}$ \\
\hline Klebsiella sp. (Isolate 2) & $\mathrm{C}$ & . & . & . & . & $\mathrm{R}$ & . & . & . & . & . & . & $\mathrm{C}$ \\
\hline Klebsiella sp. (Isolate 3) & $\mathrm{C}$ & A & $\mathrm{T}$ & . & A & G & . & G & . & . & $\mathrm{Y}$ & . & M \\
\hline Klebsiella sp. (Isolate 4) & $\mathrm{C}$ & A & $\mathrm{T}$ & . & A & G & . & G & . & . & $\mathrm{Y}$ & $\mathrm{Y}$ & $\mathrm{C}$ \\
\hline Klebsiella sp. (Isolate 5) & $\mathrm{T}$ & . & . & . & A & $\mathrm{R}$ & . & . & . & . & . & . & $\mathrm{C}$ \\
\hline Klebsiella sp. (Isolate 6) & $\mathrm{C}$ & . & . & . & A & G & . & . & . & . & . & . & . \\
\hline Klebsiella sp. (Isolate 7) & . & . & . & $\mathrm{T}$ & A & G & . & . & . & . & . & . & . \\
\hline Klebsiella sp. (Isolate 8) & $\mathrm{T}$ & . & . & $\mathrm{G}$ & A & G & . & $\mathrm{W}$ & $\mathrm{S}$ & $\mathrm{C}$ & $\mathrm{W}$ & . & . \\
\hline Klebsiella sp. (Isolate 9) & $\mathrm{C}$ & A & $\mathrm{T}$ & . & A & $\mathrm{G}$ & . & A & $\mathrm{G}$ & $\mathrm{C}$ & $\mathrm{T}$ & . & $\mathrm{C}$ \\
\hline Klebsiella sp. (Isolate 11) & $\mathrm{T}$ & . & . & $\mathrm{T}$ & A & G & $\mathrm{G}$ & . & . & . & . & . & . \\
\hline
\end{tabular}

The sequences of 16S rRNA from all isolates, except isolate 10 and 12 were aligned and compared to the sequence of $K$. pneumoniae strain ATCC 13883 (NR 119278.1) and several strains obtained from various clinical isolates such as blood, feces, urine, sputum deposited in GenBank database. There were 13 nucleotide polymorphic sites among $K$. pneumoniae group. Isolate 3, isolate 4 , and isolate 9 possessed two specific nucleotide polymorphisms that differ with all isolates in nucleotide positions 352 and 379 (Table 3). Since the sequences of isolate 10 and isolate 12 have a rather big value of genetic distance (Table 2), nucleotide blast and found that isolate 10 had high similarity with Citrobacter sp. were performed, while isolate 12 was highly similar with Micrococcus sp.
The phylogenetic relationship among all bacterial isolates of $K$. pneumoniae, Micrococcus sp., and Citrobacter sp. based on 16S rRNA gene is shown in Figure 2. In accordance with the bootstrap analysis, the tree was separated into 3 clades, namely $K$. pneumoniae (isolates 1,2,3,4,5,6,7,8,9 and 11), Citrobacter sp. (isolate 10), and Micrococcus sp. (isolate 12). All those belonging to the $K$. pneumoniae clade, including the sequences obtained from clinical isolates such as urine, sputum, pus, blood, feces, etc are clustered together. The 16S rRNA gene sequence is an effective method for bacterial identification (Ghosh and Bandyopadhyay 2019; Prabhurajeshwar and Chandrakanth 2019; Alsanie 2020). Slight differences were detected in the result of the biochemical test using API 20E for the classification of the 
isolates. Based on this, it was observed that isolates 1 to 11 were $K$. pneumoniae, while 12 were $K$. oxytoca. Conversely, in the $16 \mathrm{~S}$ rRNA gene sequence of isolates 1 to 9 , including isolate 11 were $K$. pneumoniae, while isolates 10 and 12 are Citrobacter sp. and Micrococcus sp., respectively.

Alsanie (2020) reported that from a total of 134 clinical samples, 23 isolates of $K$. pneumoniae were identified using a microbiological method and confirmed with 1365 bp of $16 \mathrm{~S}$ rRNA gene sequences. The BLAST results showed that partial 16S rRNA sequences are similar to $K$. pneumoniae strains, with relatively $98 \%$ and $97 \%$ matrix of MN-314311, and MK713647, respectively. This is a global indicator of evolution, besides all K. pneumoniae strains, be it from food or human infection, is highly homologous to this sequence. However, they are different from virulent genes (Hassan and Belal 2016; Caneiras et al. 2019;
Alsanie 2020). Furthermore, the phylogenetic tree of $16 \mathrm{~S}$ rRNA sequence of these isolates showed distinct separations between these species. There are 3 clades, and the first is $K$. pneumoniae, where isolates 1 to 9 and 10 were clustered together with other sequences from the database. Moreover, all were obtained from clinical isolates such as blood, sputum, urine, percutaneous abscess drainage, abdominal pus, and nose. Therefore, the realized isolates have potential pathogenicity that is risky to human health. Even though isolate 10 was closer to Citrobacter sp. and $K$. oxytoca, and rarely causes similar infections as $K$. pneumoniae, it is still regarded as a pathogenic bacterium that leads to health problems. Citrobacter spp. causes several invasive diseases, including urinary tract infections (UTI), respiratory tract, skin, and soft tissue (Antonara and Ardura 2018).

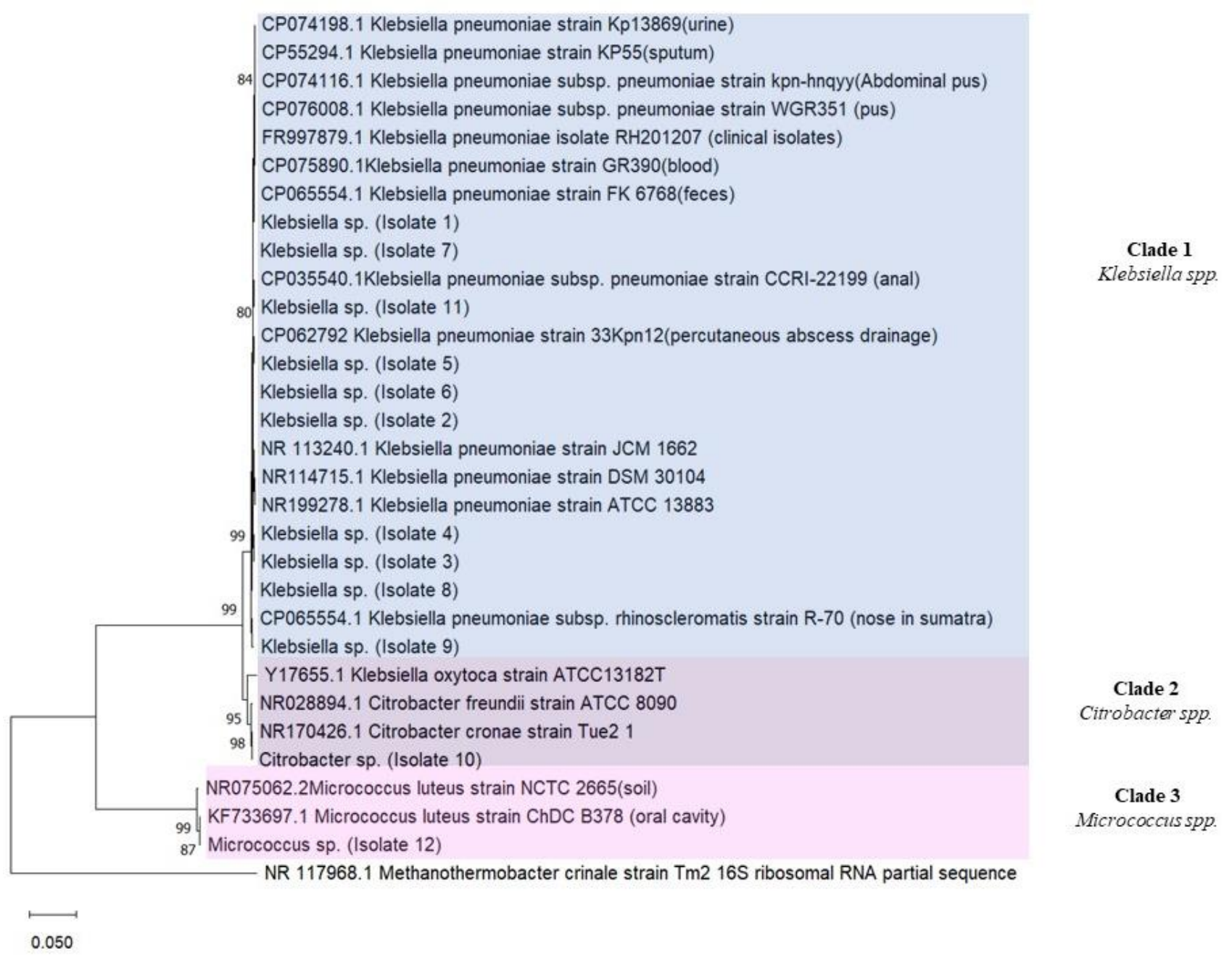

Figure 2. The phylogenetic tree of bacterial isolates from street food samples based on 16S rRNA nucleotide sequences (included $1 \mathrm{st}+2 \mathrm{nd}+3 \mathrm{rd}+$ Noncoding codon position; $\sim 1,400 \mathrm{bp}$ ). The percentage of replicate trees in which the associated taxa clustered together in the bootstrap test (1000 replicates) are shown next to the branches. The tree is drawn to scale, with branch lengths in the same units as those of the evolutionary distances used to infer the phylogenetic tree 
Meanwhile, K. oxytoca is normally detected in contaminated milk products derived from infected cows and buffaloes (Osman et al. 2014). The detection of possible pathogenic bacteria implies poor personal hygiene and sanitation. Among our isolates, isolate 12 had high similarity with Micrococcus sp. based on the blast alignment using the $16 \mathrm{~S}$ rRNA sequence. Thus, the isolate 12 clustered together with $M$. luteus from soil and oral cavity. In nature, the species belong to Micrococcus sp. were found as commensals on skin and oropharynx of mammals, an inhabitant of soil and marine sediment, and found as contaminants in several foods like chicken and fish meat (Kloos et al. 1974; Pękala et al. 2018). The contamination of street food samples by Micrococcus might happen during poor hygiene (direct contact with the seller's skin and or from the soil).

Foodborne diseases are widely reported, however the study on $K$. pneumoniae is limited, especially in edible items and drinks. A preliminary study carried out by Guo et al. (2016) stated that 998 food samples obtained from Shijiazhuang city (China) were identified using BD Phoenix ${ }^{\text {TM}}-100$ Automated Microbiology System. This included 49 fresh seafood, 188 chickens, 297 frozen foods, and 464 cooked food. In this study, 99 (9.9\%) samples tested positive for $K$. pneumoniae, and the contamination rate is $9.1 \%$. Zhang et al. (2018) studied 1,200 retail foods in 24 Chinese cities, including 312 ready-to-eat foods, 336 raw types of meats, 192 edible mushrooms, 240 aquatic products, and 120 vegetables, and discovered the presence of 61 isolates $K$. pneumoniae which is equivalent to a contamination rate of $5.08 \%$

Based on the 16S rRNA sequence analysis detected an insignificant difference between the bacterial found in the respiratory tract and urine and those in food and drinks. Bacteria are susceptible to mutations caused by their environment. However, this is part of their natural evolution, which allows them to continually adjust their genetic code (Richardson 2017). Due to the poor cost, street foods are popular in developing countries because they are preferred by low and middle-class people, irrespective of their health implications. $K$. pneumoniae and $K$. oxytoca are frequently detected in the farm environments, cow skin and milk, teet-end swabs, and clinical mastitis (Rowbotham and Ruegg 2016; Fuenzalida and Ruegg 2019). Furthermore, these species are important pathogens associated with both human and animal health. $K$. pneumoniae and $K$. oxytoca are known to cause pneumonia, liver abscesses, and urinary tract infections (Bengoechea and Pessoa 2019; Fuenzalida and Ruegg 2019).

In conclusion, it can be drawn that 120 samples of 10 species contained 7 types of street foods and drinks sold by street vendors in Yogyakarta detected 11 isolates as $K$. pneumoniae and 1 isolate as $K$. oxytoca based on biochemical tested using API 20E. However, molecular identification using the 16S rRNA gene sequence proved that 10 isolates were closely related to $K$. pneumoniae, one isolate was clustered with Citrobacter sp., and the other isolate belonged to $M$. luteus.

\section{ACKNOWLEDGEMENTS}

The authors thank the Ministry of Research, Technology, and Higher Education of the Republic of Indonesia (1867/E4/AK.04/2021 and 066/E4.1/AK.04.PT/ 2021) to Tri Yahya Budiarso for the financial support. We also thank all members of Duta Wacana Christian University's Microbiology Laboratory, Yogyakarta, Indonesia.

\section{REFERENCES}

Al-Agha AGM, Al-Khafaji NJM, Al-Azawi AKS. 2017. Isolation and identification of Klebsiella pneumoniae using API-20E analytical system and conventional PCR assay. Intl J Curr Microbiol App Sci 6 (8): 203-210. DOI: $10.20546 / \mathrm{ijcmas} .2017 .608 .028$.

Alimi BA. 2016. Risk factors in street food practices in developing countries: A review. Food Sci Hum Wellness 5: 141-148. DOI: 10.1016/j.fshw.2016.05.001.

Alsanie WF. 2020. Molecular diversity and profile analysis of virulenceassociated genes in some Klebsiella pneumoniae isolates. Practical Lab Med 19: e00152. DOI: 10.1016/j.plabm.2020.e00152.

Antonara S, Ardura MI. 2018. Citrobacter Species. Principles and Practice of Pediatric Infectious Diseases (Fifth Edition) 827-829. DOI: 10.1016/b978-0-323-40181-4.00141-9.

Bagley ST. 1985. Habitat association of Klebsiella species. Infect Control 6 (2): 52-58. DOI: 10.1017/S0195941700062603.

Barbosa J, Albano H, Silva CP, Teixeira P. 2019. Microbiological contamination of reusable plastic bags for food transportation. Food Control 99: 158-163. DOI: 10.1016/j.foodcont.2018.12.041.

Bengoechea JA, Pessoa SA. 2019. Klebsiella pneumoniae infection biology: Living to counteract host defences. FEMS Microbiol Rev 43 (2): 123-144. DOI: 10.1093/femsre/fuy043.

Caneiras C, Lito L, Mayoralas-Alises S, Díaz-Lobat S, Melo-Cristino J, Duarte A. 2019. Virulence and resistance determinants of Klebsiella pneumoniae isolated from a Portuguese tertiary university hospital centre over a 31-year period. Enfermedades Infec Mic Clin 37 (6): 387-393. DOI: 10.1016/j.eimc.2018.11.001.

Cappuccino JG, Welsh CT. 2017. Microbiology: A Laboratory Manual, $11^{\text {th }}$ Edition. Pearson Education Limited, New York.

Devenish JA, Barnum DA. 1980. Evaluation of API 20E System and Encise Enterotube for the identification of Enterobacteriaceae of animal origin. Can J Comp Med 44 (3): 315-319.

Brenner DJ, Farmer, JJ. 2015. Enterobacteriaceae: Bergey's Manual of Systematics of Archaea and Bacteria. John Wiley \& Sons, Inc. in association with Bergey's Manual Trust, New Jersey. DOI: 10.1002/9781118960608.fbm0022.

Fuenzalida MJ, Ruegg PL. 2019. Negatively controlled, randomized clinical trial to evaluate intramammary treatment of nonsevere, gramnegative clinical mastitis. J Dairy Sci 102: 5438-5457. DOI: 10.3168/jds.2018-16156.

Ghosh S, Bandyopadhyay PK. 2019. Molecular characterization of newly identified Klebsiella PKBSG14 and analysis of its effect on immune response and cell cycle progression using common catfish (Channa punctatus) as a model. Microb Pathog 127: 368-379. DOI: 10.1016/j.micpath.2018.12.026.

Guo Y, Zhou H, Qin, L, Pang Z, Qin T, Ren H, Pan Z, Zhou J. 2016. Frequency, antimicrobial resistance and genetic diversity of Klebsiella pneumoniae in food samples. PLoS One 11 (4): e0153561. DOI: $10.1371 /$ journal.pone.0153561.

Hamza E, Dorgham SM, Hamza DA. 2016. Carbapenemase-producing Klebsiella pneumoniae in broiler poultry farming in Egypt. J Glob Antimicrob Resist 7: 8-10. DOI: 10.1016/j.jgar.2016.06.004.

Harada T, Taguchi M, Kawahara R, Kanki M, Kawatsu K. 2018. Prevalence and antimicrobial susceptibility of bacterial pathogens in ready-to-eat foods retailed in Osaka Prefecture, Japan. J Food Prot 81 (9): 1450-1458. DOI: 10.4315/0362-028X.JFP-18-035.

Hassan MM, Belal ESB. 2016. Antibiotic resistance and virulence genes in Enterococcus strains isolated from different hospitals in Saudi Arabia. Biotechnol Biotechnol Equip 30 (4): 726-732. DOI: 10.1080/13102818.2016.1184992. 
Ibrahim IA. 2016. 16S rRNA gene sequencing for identification of some enterobacteriaceae species isolated from tigris river. Al-Mustansiriyah J Sci 27 (3): 13-16

Kim HS, Chon JW, Kim YJ, Kim DH, Kim M and Seo KH. 2015 Prevalence and characterization of extended-spectrum- $\beta$-lactamaseproducing Escherichia coli and Klebsiella pneumoniae in ready-to-eat vegetables. Intl $\mathrm{J}$ of Food Microbiol 207: 83-86. DOI: 10.1016/j.ijfoodmicro.2015.04.049.

Kloos WE, Tornabene TG, Schleifer KH. 1974. Isolation and characterization of Micrococci from human skin, including two new species: Micrococcus lylae and Micrococcus kristinae. Intl J Syst Bacteriol 24: 79-101. DOI: 10.1099/00207713-24-1-79.

Kumar S, Stecher G, Tamura K. 2016. MEGA7: Molecular evolutionary genetics analysis version 7.0 for bigger datasets. Mol Bio Evol 33 (7): 1870-1874. DOI: 10.1093/molbev/msw054.

Langoni H, Guiduce MVS, Nobrega DB, da Silva RC, Richini-Pereira VB, Salina, Guimaraes, FDF. 2015. Research of Klebsiella pneumoniae in dairy herds. Pesq Vet Bras 35 (1): 9-12. DOI: 10.1590/S0100-736X2015000100003.

Maina D, Okinda N, Mulwa E, Revathi G. 2014. A five year review of Api20e bacteria identification system's performance at a teaching hospital. East Afr Med 91 (3): 73-76.

Maisonneuve E, Cateau E, Delouche M, Quellard N, Rodier MH 2017. An observational study of phagocytes and Klebsiella pneumoniae relationships: Different behaviors. Microbes Infect 19 (4 5): 259-266. DOI: 10.1016/j.micinf.2016.12.005.

Maheux AF, Bouchard S, Bérubé E, Bergeron MG. 2017. Comparison of MI, Chromocult ${ }^{\circledR}$ coliform, and compass CC chromogenic culturebased methods to detect Escherichia coli and total coliforms in water using 16S rRNA sequencing for colony identification. J Water Health 15 (3): 353-359. DOI: 10.2166/wh.2017.174

Onuoha SC, Okafor CO, Aduo BC. 2016. Antibiotic and heavy metal tolerance of bacterial pathogens isolated from agricultural soil. World J Med Sci 13 (4): 236-241.

Osman KM, Hassan HM, Orabi A, Abdelhafez AST. 2014. Phenotypic, antimicrobial susceptibility profile and virulence factors of Klebsiella pneumoniae isolated from buffalo and cow mastitic milk. Pathog Glob Health 108 (4): 191-199. DOI: 10.1179/2047773214Y.0000000141.

Pękala A, Paździor E, Antychowicz J, Bernad A, Głowacka H, Więcek B, Niemczuk W, 2018. Kocuria rhizophila and Micrococcus luteus as emerging opportunist pathogens in brown trout (Salmo trutta Linnaeus, 1758) and rainbow trout (Oncorhynchus mykiss Walbaum, 1792). Aquaculture 486: 285-289. DOI: 10.1016/j.aquaculture.2017.12.028.
Prabhurajeshwar C, Chandrakanth K. 2019. Evaluation of antimicrobial properties and their substances against pathogenic bacteria in vitro by probiotic Lactobacilli strains isolated from commercial yoghurt. Clin Nutr Exp 23: 97-115. DOI: 10.1016/j.yclnex.2018.10.001.

Ramaditya NA, Tono K, Suarjana IGK, Besung, INK. 2018. Isolation Klebsiella sp. at Bali cattle based on level of maturity and breeding location and the pattern of sensitivity against antibacterial. Bul Vet Udayana 10 (1): 26-32. DOI: 10.24843/bulvet.2018.v10.i01.p04.

Richardson LA. 2017. Understanding and overcoming antibiotic resistance. PLoS Biol 15 (8): e2003775. DOI: 10.1371/journal.pbio.2003775.

Rowbotham RF, Ruegg, PL. 2016. Bacterial counts on teat skin and in new sand, recycled sand, and recycled manure solids used as bedding in freestalls. J Dairy Sci 99 (8): 6594-6608. DOI: 10.3168/jds.201510674.

Saini M, Raj A, Bhattacharyya S, Banik A, Chattopadhyay UK. 2016. Prevalence of Klebsiella oxytoca in milk samples of metropolitan city Kolkata: A study. Eastern J Med Sci 5 (1):16-18. DOI: 10.32677/EJMS.2020.v05.i01.005.

Salazar, JK, Carstens CK, Ramachandran P, Shazer AG, Narula SS, Reed E, Ottensen A Schill KM. 2018. Metagenomics of pasteurized and unpasteurized gouda cheese using targeted 16S rDNA sequencing. BMC Microbiol 18: 189. DOI: 10.1186/s12866-018-1323-4.

Shiningeni D, Chimwamurombe P, Shilangale R, Misihairabgwi J. 2018. Prevalence of pathogenic bacteria in street vended ready-to-eat meats in Windhoek, Namibia. Meat Sci 148: 223-228. DOI: 10.1016/j.meatsci.2018.05.014.

Son KL, Nugroho ASD, Rahayujati B, Gozali. 2019. Food Poisoning Outbreak Caused by Diarrhoeal Bacillus Cereus in Tegalkenongo Village, Bantul, Yogyakarta, Indonesia: A Retrospective Study. Asia Pac Fam Med 18 (1): 1-5. DOI: 10.22146/apfm.v18i1.62.

Suryani D, Sunarti, Safitri RA, Khofifah H, Suyitno. 2021. Identification of coliform bacteria content in 'Thai Tea' drinks and its correlation with hygiene factors in Yogyakarta, Indonesia. Publ Health Indonesia 7 (1): 41-47. DOI: $10.36685 /$ phi.v7i1.388.

Teramura H, Sota K, Iwasaki M, Ogihara H. 2017. Comparison of the quantitative dry culture methods with both conventional media and most probable number method for the enumeration of coliforms and Escherichia coli /coliforms in food. Lett App Microbiol 65 (1): 57-65. DOI: $10.1111 /$ lam.12744.

Zhang S, Yang G, Ye Q, Wu Q, Zhang J, Huang Y. 2018. Phenotypic and genotypic characterization of Klebsiella pneumoniae isolated from retail foods in China. Front Microbiol 9:289. DOI: 10.3389/fmicb.2018.00289. 